\title{
三次元異方性異種材接合角部の特異応力場解析
}

\author{
古賀 裕二*1，田口 陽介 ${ }^{* 2}$ ，小金丸 正明*3，池田 徹*4，宮崎 則幸*5
}

\section{Development of the singular stress analyses for three-dimensional interfacial corners}

\author{
Yuji KOGA ${ }^{* 1}$, Yosuke TAGUCHI ${ }^{* 2}$, Masaaki KOGANEMARU*3 ${ }^{* 3}$, Toru IKEDA ${ }^{* 4}$ \\ and Noriyuki MIYAZAKI*5 \\ ${ }^{*} 1,{ }^{* 3},{ }^{* 4}$ Department of Mechanical Engineering, Kagoshima University, 1-21-40 Korimoto, Kagoshima, Kagoshima 890-0065, Japan \\ ${ }^{* 2}$ Kawasaki Heavy Industries, Ltd., 1-1 Kawasaki-Cho, Akashi, Hyogo 673-8666, Japan \\ ${ }^{* 5}$ Green Electronics Research Institute, Kitakyushu, 1-8 Hibikino, Wakamatsu-ku, Kitakyushu, Fukuoka 808-0135, Japan
}

Received: 28 August 2016; Revised: 8 October 2016; Accepted: 2 December 2016

\begin{abstract}
We proposed a new technique to analyze the asymptotic solution around a three dimensional interface corners. We analyzed the scalar parameters of the asymptotic solutions using the $H$-integral, which is a conservative integral, in conjunction with the finite element analysis. Singular orders of these three-dimensional corners were obtained using the finite element method for the eigen analysis. If $\lambda$ is an eigen value of a three dimensional corner, $-\lambda-1$ is also an eigen value. Complementary eigen values and eigen vectors are used for the $H$-integral analysis to obtain the scalar parameters. If we select the eigenvalue, $-\lambda-1$, as the complementary eigenvalue for the $H$-integral, the $H$-integral corresponds with a scalar parameter of the asymptotic solution. We proposed the normalization of the eigenvalues for defining the obtained scalar parameters as the unique values. We demonstrate that the obtained asymptotic solutions correspond well with the stress field obtained by the finite element analyses around three-dimensional interface corners.
\end{abstract}

Key words: Three-dimensional corners, Asymptotic solution, Scalar parameter, Eigen value, $H$-integral, Conservative integral

\section{1. 緒言}

近年，携帯電話やノートパソコンなどの電子機器は小型で軽量，かつ高性能なものの開発が行われている。こ のような電子機器に組み込まれる電子デバイスなども小型化が実現されているが，これらの小型化は多種多様な 性質の材料を限られた小さな範囲に積層する技術により達成されている，これら電子デバイスのように，性質の 異なる材料を積層することで有用な働きを持たせている構造物などには多くの接合界面が生じ，その接合角部に は材料定数の違いにより特異応力場が発生する．接合角部は，き裂が発生するなど破壊の起点となることがある ため, 接合角部での強度信頼性や破壊の挙動評価のためにも接合角部における特異応力場の評価手法の確立が求 められている.

これまで, 異種材接合角部の特異応力場の研究は, 多くの研究者によって行われてきた. William は, 固有值 展開法を用いて，均質体中の鋭い Vノッチ周りの応力場の特異性固有值と固有関数を求め(Williams, 1952), これ をき裂周りの応力場にまで拡張して議論している(Williams, 1957). 実際の応力場を明らかにするには, Williamの 固有值展開法による式のスカラーパラメーターや応力拡大係数を求めることが必要である. Stern ら(Sterm et al., 1976)や Sinclair ら(Sinclair et al., 1984)は，Betti の相反定理に基づいた $H$-integral によって，均質体中のき裂の応力

\footnotetext{
No.16-00382 [DOI:10.1299/transjsme.16-00382], J-STAGE Advance Publication date: 16 December, 2016

*1 鹿児島大学大学院 理工学研究科（广890-0065 鹿児島県鹿児島市郡元 1-21-40）

$*_{2}$ 川崎重工業（株）（广673-8666 兵庫県明石市川崎町 1-1）

*3 正員, 鹿児島大学学術研究院 理工学域工学系

*4 正員, フェロー, 鹿児島大学学術研究院 理工学域工学系

*5 正員，フェロー，北九州市環境エレクトロニクス研究所（广808-0135 福岡県北九州市若松区ひびきの 1-8）

E-mail of corresponding author: ikeda@mech.kagoshima-u.ac.jp
} 
拡大係数を求めている. Carpenter は, $H$-integral を用いて, 任意の開き角の V ノッチの応力拡大係数を求めた (Carpenter, 1984). 異方性材料の接合角部の特異性指数については, Labossiere らが $H$-integral を用いて, 異方性異 種材接合角部のスカラーパラメーターを求めた (Labossiere and Dunn, 1999). さらにHwu らが Key Matrix を提唱 し, 多種の異方性材料が接合された接合角部の特異性固有值と固有関数を解析的に求められるようになった (Hwu et al., 2003). Hwu らはさらに $H$-integral を用いて機械的荷重下の異方性異種材接合角部のスカラーパラメー ターを求めるだけでなく, 異種材接合角部からき裂までを統一的に示寸応力拡大係数の定義を提案した (Hwu and Kuo, 2007). 野村らは, 熱応力と機械的荷重が共に負荷される場合のスカラーパラメーターを $H$-integral を改良し て求め, Hwu らの提唱した応力拡大係数のより実用性の高い定義を提案した (Nomura et al., 2009). また, 接合角 部近傍で平面ひずみとみなせるような疑似 3 次元問題の応力拡大係数の解析を行った (Nomura et al., 2010).

しかし，実際の破壊現象では完全な 3 次元角部，接合角部のエッジ部分のような角部からの破壊が問題となる ことも多く,こういった 3 次元角部での応力集中の評価手法の確立が求められている. 完全な 3 次元接合角部の 特異性固有值と固有関数を求める手法は, Pegeau らによって, 有限要素法を用いた固有值解析手法として数值的 に解析する手法が提案されている (Pegeau et al., 1995). この手法は古口らによって, 境界要素法にも適用された (Koguchi and Muramoto, 2000). 著者らは, 前報(池田他, 2013)において, 有限要素法解析を用いて三次元接合角部 の特性応力場の固有值解析を行い, $H$-integral 法を用いてスカラーパラメーターを解析し, 応力の漸近解を求める 方法を提案した. $H$-integral 法によってスカラーパラメーターを求めるには, 適切な補助解を選ぶ必要がある. 2 次元問題においては，対象とする問題の特異性固有值が $\lambda$ のとき， $-\lambda$ もまた特異性固有值の一つになることを利 用して, $H$-integral がスカラーパラメーターに一致するように- $\lambda$ を補助解に選択した. 2 次元問題においては,

$\mathrm{Wu}$ らによって特異性固有值が $\lambda$ のとき, $\lambda$ もまた特異性固有值の一つになることが解析的に示されている(Wu et al., 1993). 古口らは，三次元問題においては， $H$-integral に用いる補助解の特異性指数は 3- $\lambda$ に設定寸ることが有 効であるとして, 固有值が単一の実数解である場合のスカラーパラメーターを求めた(Luangarpa and Koguchi, 2014). 本研究では, 2 次元問題で用いた手法を 3 次元問題に拡張して, 固有値とスカラーパラメーターが複数あ る場合に，それぞれのスカラーパラメーターを $H$-integral により求めることができることを半解析的な方法で証 明した. 古口らと著者らの漸近解の定義の違いにより, 著者らの漸近解と定義では- $\lambda-1$ を補助解にとったが, こ れは古口らの補助解の特異性指数 3- $\lambda$ と本質的に同じである. 本研究では, $-\lambda-1$ を補助解にとることにより, $H$-integral の值が複数のスカラーパラメーターに収束することを理論的に考察した. また, 前報(池田他, 2013)にお いては, 固有值を求める有限要素分割数を変化させると固有関数とスカラーパラメーターが変動するなどの問題 が見られた. これは, 求めた固有関数がスカラー乗倍の無数の解を持つことに起因しており, 固有関数を正規化 する定義を導入することで，一意的にスカラーパラメーターを求められることを示す．これにより，求めたスカ ラーパラメーターを破壊の支配パラメーターに結びつけることが容易になることが期待できる.

\section{2. 解析理論}

\section{$2 \cdot 1$ 特異応力 $\cdot$ 変位場}

Williams の固有值展開法(Williams, 1952, 1957, Labossiere and Dunn, 1999, Banks-Sills and Ishbir, 2004, Munz et al., 1993)によれば角部の特異点を原点として, 特異点からの距離を $r$ とすると角部近傍の応力, 変位は次式のように 表すことができる.

$$
\begin{aligned}
\sigma_{i j}^{k} & =\sum_{m=1}^{\mathrm{N}} C_{m} r^{\lambda_{m}-1} f_{i j}^{m k}(\theta, \phi) \\
u_{i}^{k} & =\sum_{m=1}^{\mathrm{N}} C_{m} r^{\lambda_{m}} g_{i}^{m k}(\theta, \phi)
\end{aligned}
$$



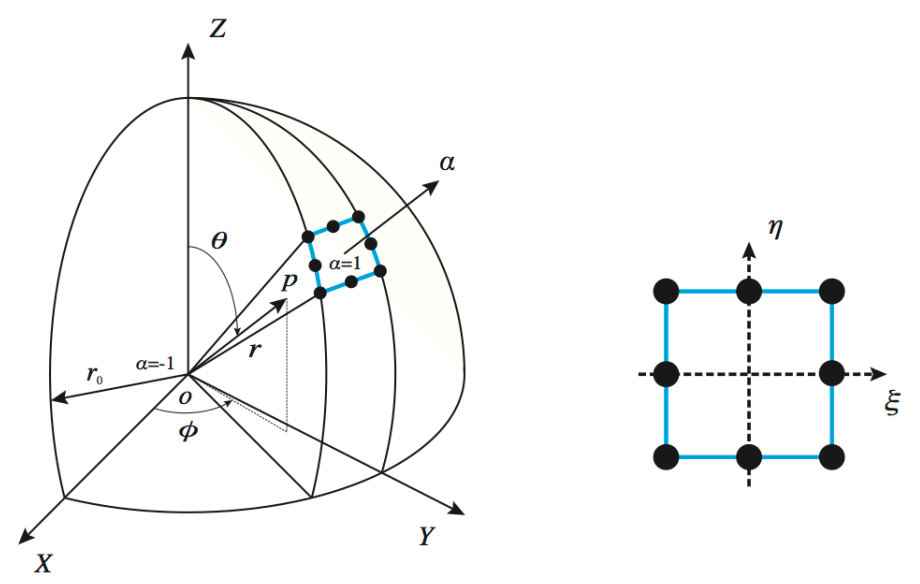

Fig. 1 Definition of the element geometry and the polar coordinates around a three-dimensional singular point.

ここで, $C_{m}$ はスカラーパラメーターと呼ばれる定数值であり, 後述する $H$-integral によって求められる. また, $\lambda_{m}$ は特異性固有值, $f_{i j}^{m k}(\theta, \phi), g_{i}^{m k}(\theta, \phi)$ は特異性固有值に対応寸る固有関数で, これらは $2 つ の$ 材料の材料定数と角 部の形状を表す角度から決定され，負荷条件には依らない。

\section{$2 \cdot 2$ 特異性指数解析}

本研究では特異性指数と固有関数を Pageau ら(Pageau and Biggers, 1995)が提案する方法によって求めた. 点 $o$ の特異点周りの領域を図 1 のような要素に分割すると要素内のある点での変位 $\bar{u}$ は次のように表せる.

$$
\begin{aligned}
& \bar{u}=\rho^{\lambda}\left[\sum_{i=1}^{n} \Omega_{i} \bar{u}_{i}\right] \\
& \rho=r / r_{0}
\end{aligned}
$$

ここで, $n$ は節点数で本研究では 8 節点要素を用いたので $n=8$ である. $r$ は要素内点までの距離, $r_{0}$ は要素の半径, 的 は節点での変位， $\Omega_{i}$ は内挿関数である. この要素に仮想仕事の原理を用いることで以下の式が導ける.

$$
\left(\lambda^{2}[A]+\lambda[B]+[C]\right)\{\bar{U}\}=0
$$

式 (3) は以下の式 (4) のように変形することができ, 式 (4) の固有值問題を解くことで固有指数 $\lambda$ が得られる.

$$
\left[\begin{array}{cc}
0 & I \\
-A^{-1} C & -A^{-1} B
\end{array}\right]\left\{\begin{array}{c}
\bar{V} \\
\bar{U}
\end{array}\right\}=\lambda\left\{\begin{array}{c}
\bar{V} \\
\bar{U}
\end{array}\right\}
$$

実際には, 次式のように変形し, 疎行列の一般化固有值分解として解析した. 


$$
\left[\begin{array}{cc}
0 & I \\
-C & -B
\end{array}\right]\left\{\begin{array}{c}
\bar{V} \\
\bar{U}
\end{array}\right\}=\left[\begin{array}{ll}
I & 0 \\
0 & A
\end{array}\right] \lambda\left\{\begin{array}{c}
\bar{V} \\
\bar{U}
\end{array}\right\}
$$

このとき, $\bar{U}$ より得られる各要素の節点変位を $\bar{u}_{i}$ とするとき, $g_{i}^{m k}(\theta, \phi)$ を次式のように設定する.

$$
g_{i}^{m k}(\theta, \phi)=\left[\sum_{i=1}^{n} \Omega_{i} \bar{u}_{i}\right]
$$

このとき, $f_{i j}^{m k}(\theta, \phi)$ は, 次式で示される.

$$
f_{i j}^{m k}(\theta, \phi)=[D]\left[\sum_{i=1}^{n}\left(\lambda_{m} B_{i a}+B_{i b}\right) \bar{u}_{i}\right]
$$

ここで, $D$ は弾性マトリックス $B_{a}$ と $B_{b}$ は変位-ひずみマトリックスの一部であり, $k$ は各材料を示している. しかし, 固有関数はスカラー数倍の無数の解を持っため, 後述する $H$-integral によって得られるスカラーパラメ 一ターも無数の解を持つことになる，そこで一義的にスカラーパラメーターを求めるために，次式を満たすよう に節点変位を正規化した．この正規化した節点変位を用いることで，計算により一義的にスカラーパラメーター を得ることを可能にした. 前報(池田他, 2013)において, 有限要素分割数によってスカラーパラメーターが変動 した原因もこの正規化を行わなかったことに起因することが判明した.

$$
\frac{\int\left|g_{i}^{m k}(\theta, \phi)\right|^{2} d S}{\int \gamma d S}=1
$$

ここで, $\gamma$ は任意の正規化定数である.

\section{$2 \cdot 3 \quad H$-integral}

Betti の相反定理に基づき, 特異点を含まない弾性体中の任意の領域 $V に$ 対して, 次式が成り立つ.

$$
\int_{V}\left(\sigma_{i j} \varepsilon_{i j}^{*}-\sigma_{i j}^{*} \varepsilon_{i j}\right) d V=0
$$

ここで， $\sigma_{i j}, \varepsilon_{i}$ は第一の応力とひずみ， $\sigma_{i j}{ }^{*}, \varepsilon_{i}{ }^{*}$ は第二の応力とひずみである. Gauss の発散定理により，次式が 得られる.

$$
\begin{aligned}
\int_{V}\left(\sigma_{i j} \varepsilon_{i j}^{*}-\sigma_{i j}^{*} \varepsilon_{i j}\right) d V & =\int_{V}\left(\sigma_{i j} u_{i, j}^{*}-\sigma_{i j}^{*} u_{i, j}\right) d V \\
& =\int_{S}\left(\sigma_{i j} u_{i}^{*}-\sigma_{i j}^{*} u_{i}\right) n_{j} d S=0
\end{aligned}
$$

ここで, $S$ は $V$ を囲む面である. また, *の付いていない $\sigma_{i j}$ と $u_{i}$ は第 1 番目の応力と変位であり, 以下解析対象 とする. 一方で, *の付いた $\sigma_{i j}^{*}$ と $u_{i}^{*}$ は第 2 番目の応力と変位であり, 以下補助場とする. 次に, 図 2 の特異点 $o$ 
まわりに特異点を囲むような領域を考える. 図 2 に示すように $S_{r}$ は特異点 $o$ からの距離 $r$ である球面, $S_{\varepsilon}$ は特異 点 $o$ からの距離 $\varepsilon$ である球面, $S_{1}, S_{2}, S_{3}$ は自由表面を示している. $S_{1}, S_{2}, S_{3}$ 上で補助場も自由表面の境界条件をと るように選択すると，積分值は 0 となる．そのため, $S_{r}$ と $S_{\varepsilon}$ が残り, 次式が得られる.

$$
\int_{S_{r}}\left(\sigma_{i j} u_{i}^{*}-\sigma_{i j}^{*} u_{i}\right) n_{j} d S+\int_{S_{\varepsilon}}\left(\sigma_{i j} u_{i}^{*}-\sigma_{i j}^{*} u_{i}\right) n_{j} d S=0
$$

次に $S_{\varepsilon}{ }^{\prime} と し て S_{\varepsilon}$ の反対側，つまり反対向きの法線ベクトルを持つ面を考えると，式(9)は次式のようになる.

$$
\int_{S_{\varepsilon}^{\prime}}\left(\sigma_{i j} u_{i}^{*}-\sigma_{i j}^{*} u_{i}\right) n_{j} d S=\int_{S_{r}}\left(\sigma_{i j} u_{i}^{*}-\sigma_{i j}^{*} u_{i}\right) n_{j} d S
$$

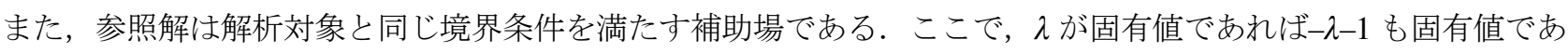
ると仮定し，式（1）に $\lambda=-\lambda-1$ を代入したものを参照解とした． $\lambda$ が固有值であれば- $\lambda-1$ も固有值であること は, 後述するように数值的に確認した. 次式に参照解を示す.

$$
\begin{aligned}
& \sigma_{i j}^{k^{*}}=C_{m}^{*} r^{-\lambda_{m}-2} f_{i j}^{m k^{*}}(\theta, \phi) \\
& u_{i}^{k^{*}}=C_{m}^{*} r^{-\lambda_{m}-1} g_{i}^{m k^{*}}(\theta, \phi)
\end{aligned}
$$

ここで, $f_{i j}^{m k^{*}}(\theta, \phi)$ と $g_{i}^{m k^{*}}(\theta, \phi)$ は, 式(5)を解いた際に固有值- $\lambda-1$ に対応した固有ベクトルを式(6), 式(7)に適用し て求める.このとき, 式(10)の左辺は $m=\mathrm{I}$ を選ぶとき, 次式で示される.

$$
\begin{aligned}
& H_{\mathrm{I}}=\lim _{\varepsilon \rightarrow 0} \iint\left(\sigma_{i j}^{k} u_{i}^{k^{*}}-\sigma_{i j}^{k^{*}} u_{i}^{k}\right) n_{j} \varepsilon^{2} \sin \theta d \theta d \phi \\
& =\lim _{\varepsilon \rightarrow 0} \iint\left(\sigma_{r r} u_{r}^{*}+\sigma_{r \theta} u_{\theta}^{*}+\sigma_{r \phi} u_{\phi}^{*}-\sigma_{r r}^{*} u_{r}-\sigma_{r \theta}^{*} u_{\theta}-\sigma_{r \phi}^{*} u_{\phi}\right) n_{r} \varepsilon^{2} \sin \theta d \theta d \phi \\
& =\lim _{\varepsilon \rightarrow 0} \iint\left(C _ { I } C _ { I } ^ { * } \left(f_{r r}^{I}(\theta, \phi) g_{r}^{I *}(\theta, \phi)+f_{r \theta}^{I}(\theta, \phi) g_{\theta}^{I *}(\theta, \phi)+f_{r \phi}^{I}(\theta, \phi) g_{\phi}^{I *}(\theta, \phi)\right.\right. \\
& \left.-f_{r r}^{I^{*}}(\theta, \phi) g_{r}^{I}(\theta, \phi)-f_{r \theta}^{I *}(\theta, \phi) g_{\theta}^{I}(\theta, \phi)-f_{r \phi}^{I *}(\theta, \phi) g_{\phi}^{I}(\theta, \phi)\right) \\
& +C_{I I} C_{I}^{*} \varepsilon^{\lambda_{I^{\prime}}-\lambda_{I}}\left(f_{r r}^{I I}(\theta, \phi) g_{r}^{I^{*}}(\theta, \phi)+f_{r \theta}^{I I}(\theta, \phi) g_{\theta}^{I^{*}}(\theta, \phi)+f_{r \phi}^{I I}(\theta, \phi) g_{\phi}^{I^{*}}(\theta, \phi)\right. \\
& \left.-f_{r r}^{I^{*}}(\theta, \phi) g_{r}^{I I}(\theta, \phi)-f_{r \theta}^{I *}(\theta, \phi) g_{\theta}^{I I}(\theta, \phi)-f_{r \phi}^{I *}(\theta, \phi) g_{\phi}^{I I}(\theta, \phi)\right) \\
& +C_{I I I} C_{I}^{*} \varepsilon^{\lambda_{I I I}-\lambda_{l}}\left(f_{r r}^{I I I}(\theta, \phi) g_{r}^{I^{*}}(\theta, \phi)+f_{r \theta}^{I I I}(\theta, \phi) g_{\theta}^{I^{* *}}(\theta, \phi)+f_{r \phi}^{I I I}(\theta, \phi) g_{\phi}^{I^{* *}}(\theta, \phi)\right. \\
& \left.-f_{r r}^{I *}(\theta, \phi) g_{r}^{I I I}(\theta, \phi)-f_{r \theta}^{I *}(\theta, \phi) g_{\theta}^{I I I}(\theta, \phi)-f_{r \phi}^{I *}(\theta, \phi) g_{\phi}^{I I I}(\theta, \phi)\right) \\
& +C_{I V} C_{I}^{*} \varepsilon^{\lambda_{I V}-\lambda_{I}}\left(f_{r r}^{I V}(\theta, \phi) g_{r}^{I^{*}}(\theta, \phi)+f_{r \theta}^{I V}(\theta, \phi) g_{\theta}^{I^{* *}}(\theta, \phi)+f_{r \phi}^{I V}(\theta, \phi) g_{\phi}^{I^{*}}(\theta, \phi)\right. \\
& \left.\left.-f_{r r}^{I^{*}}(\theta, \phi) g_{r}^{I V}(\theta, \phi)-f_{r \theta}^{I^{*}}(\theta, \phi) g_{\theta}^{I V}(\theta, \phi)-f_{r \phi}^{I^{*}}(\theta, \phi) g_{\phi}^{I V}(\theta, \phi)\right)\right) n_{r} \sin \theta d \theta d \phi
\end{aligned}
$$

参照解に- $\lambda-1$ を選ぶことで, 微小項の $\varepsilon^{2}$ が相殺されて, 積分值が 0 でない有限值となる. ここで, 積分は球面上 に行っているので, 法線ベクトルの半径方向成分 $n_{r}$ は, $n_{r}=1$ である. また,

$$
\iint\left(f_{i j}^{l k}(\theta, \phi) g_{i}^{m k^{*}}(\theta, \phi)-f_{i j}^{m k^{*}}(\theta, \phi) g_{i}^{l k}(\theta, \phi)\right) \sin \theta d \theta d \phi=0 \quad l \neq m
$$




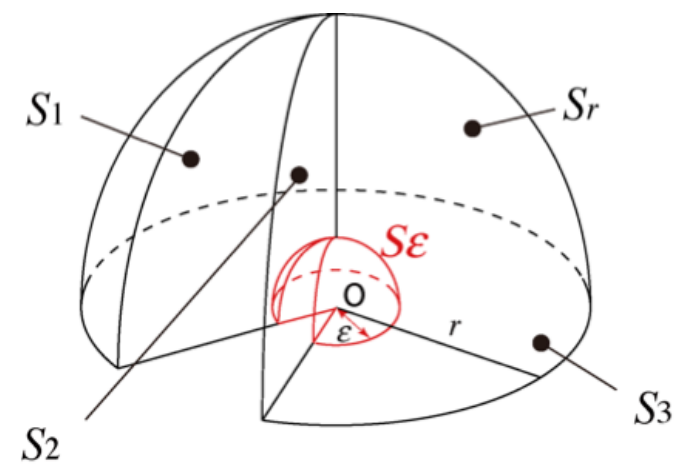

Fig. 2 Domain and boundary surfaces for the $H$-integral.

と仮定すると次式が成り立つ. 式(15)が正しいことを解析的に証明することは難しく，実際の解析例で数值的に 示す.

$$
\begin{gathered}
H_{I}=\lim _{\varepsilon \rightarrow 0} \iint C_{I} C_{I}^{*}\left(f_{r r}^{I}(\theta, \phi) g_{r}^{I^{*}}(\theta, \phi)+f_{r \theta}^{I}(\theta, \phi) g_{\theta}^{I^{*}}(\theta, \phi)+f_{r \phi}^{I}(\theta, \phi) g_{\phi}^{I^{*}}(\theta, \phi)\right. \\
\left.-f_{r r}^{I^{*}}(\theta, \phi) g_{r}^{I}(\theta, \phi)-f_{r \theta}^{I *}(\theta, \phi) g_{\theta}^{I}(\theta, \phi)-f_{r \phi}^{I *}(\theta, \phi) g_{\phi}^{I}(\theta, \phi)\right) \sin \theta d \theta d \phi
\end{gathered}
$$

$C_{m}{ }^{*}$ を次式の様に設定する.

$$
\frac{1}{C_{m}^{*}}=\iint\left(f_{i j}^{m k}(\theta, \phi) g_{i}^{m k *}(\theta, \phi)-f_{i j}^{m k *}(\theta, \phi) g_{i}^{m k}(\theta, \phi)\right) \sin (\theta) d \theta d \phi
$$

このように $C_{m}{ }^{*}$ を設定することにより,$m=\mathrm{I}$ のとき， $H_{\mathrm{I}}=C_{\mathrm{I}}$ となる．また， $m=\mathrm{II}, \mathrm{III}, \mathrm{IV}$ の場合も補助場に $-\lambda_{\mathrm{II}}-1$, $-\lambda_{\mathrm{III}}-1,-\lambda_{\mathrm{IV}}-1$ を代入して, 式(14)と同様の式展開を行うことで, $H_{m}=C_{m}$ となる. このとき, 式(12)より, $H$-integral の值は角部先端を囲むような次式の $S_{r}$ 上の積分を行うことにより求められる． $S_{r}$ は特に球面上を積分する必要は 無いが，本論文の例では，固有值解析に用いた図 1 の有限要素をそのまま用いて，一定半径の部分球上を積分し た.

$$
H=\int_{S_{r}}\left(\sigma_{i j} u_{i}^{*}-\sigma_{i j}^{*} u_{i}\right) n_{j} d S
$$

$H$-integral の積分では, 実応力と変位を通常の有限要素解析により求め, 補助解には式(5)より求めた補助解の固有 值- $\lambda-1$ とそれに対応した固有べクトルより, 式(6)(7)(13)を用いて求めた $u_{i}^{*} と \sigma_{i}^{*}$ を用いた.

\section{3. 解析結果}

\section{3-1 異種材接合角部 I}

解析モデルとして図 3 に示寸ような接合体に一様引張り $\sigma_{x x}{ }^{0}$ を加えた場合を考える. このモデルについて, 以 下 2 種類の解析を行った．モデル形状は， $W=T=2.0 \mathrm{~mm}, w=t=1.0 \mathrm{~mm}$, 及び $L=1.0 \mathrm{~mm}$ とした.

\section{$3 \cdot 1 \cdot 1$ 材料がともに等方性材料の場合}



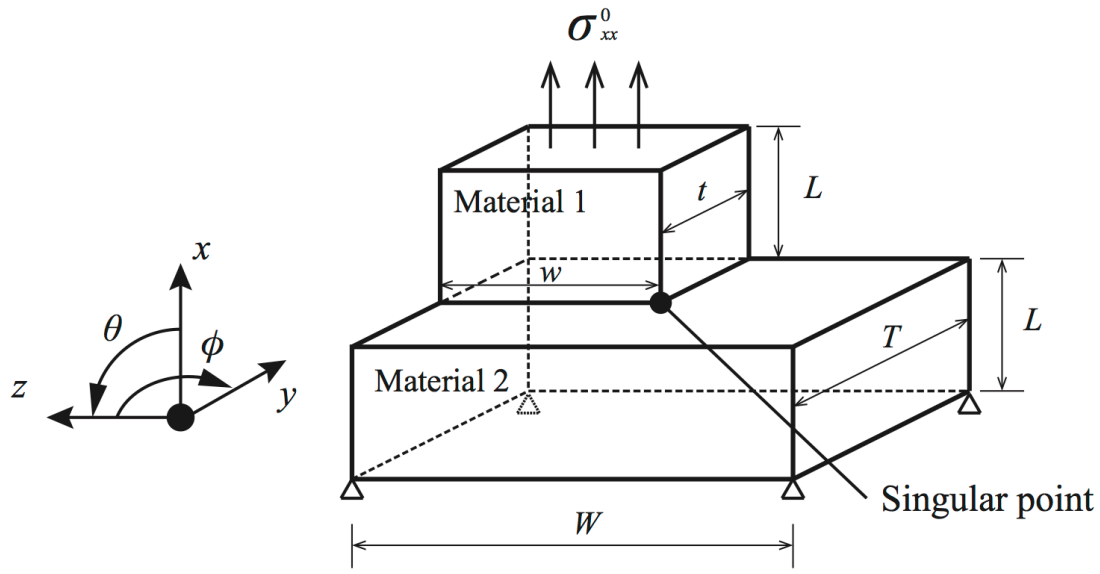

Fig. 3 Schematic of an analysis model (Model I).

Table 1 Material properties of materials 1 and 2 in Fig. 3 (Model I, Isotropic).

\begin{tabular}{ccccc}
\hline & Material & & 1 & 2 \\
\hline Young's modulus & $E(\mathrm{GPa})$ & 0.726 & 72.6 \\
\hline Poisson's ratio & $N$ & 0.3 & 0.3 \\
\hline
\end{tabular}

Table 2 Obtained eigenvalues (FE Elements in Fig. 1=2000, Model I, Isotropic).

\begin{tabular}{cccccccc}
\hline & $\lambda_{\mathrm{III}}{ }^{*}$ & $\lambda_{\mathrm{II}}{ }^{*}$ & $\lambda_{\mathrm{I}}{ }^{*}$ & & $\lambda_{\mathrm{I}}$ & $\lambda_{\mathrm{II}}$ & $\lambda_{\mathrm{III}}$ \\
\hline Eigenvalues & -1.9983 & -1.9969 & -1.6198 & -1.0001 & 0.6198 & 0.9969 & 0.9983 \\
\hline
\end{tabular}

Table 3 Obtained scalar parameters $(H$-integral meshes $=2000$, Model I, Isotropic).

\begin{tabular}{cccc}
\hline$\left(\mathrm{N} \cdot \mathrm{mm}^{-1-\lambda}\right)$ & $C_{\mathrm{I}}$ & $C_{\mathrm{II}}$ & $C_{\mathrm{III}}$ \\
\hline Scalar parameter & 10.7743 & -0.0014 & 2.2217 \\
\hline
\end{tabular}

Table 4 Integrated values of Eq. (13) ( $H$-integral meshes $=2000$, Model I, Isotropic).

\begin{tabular}{ccccccc}
\hline Elements & $l=\mathrm{I}, m=\mathrm{II}$ & $l=\mathrm{I}, m=\mathrm{III}$ & $l=\mathrm{II}, m=\mathrm{I}$ & $l=\mathrm{II}, m=\mathrm{III}$ & $l=\mathrm{III}, m=\mathrm{I}$ & $l=\mathrm{III}, m=\mathrm{II}$ \\
\hline 2000 & $1.920 \times 10^{-9}$ & $1.487 \times 10^{-8}$ & $2.253 \times 10^{-9}$ & $6.375 \times 10^{-6}$ & $5.452 \times 10^{-9}$ & $2.388 \times 10^{-6}$ \\
\hline
\end{tabular}

材料 1,2 ともに等方性材料の接合体を考え, 一様引張り $\sigma_{x x}{ }^{0}=50.0 \mathrm{MPa}$ を加えた場合の接合角部の漸近解の解 析を行った. 用いた材料定数を表 1 に, 固有值分解の結果として求めた特異性指数を表 2 に, $H$-integral によって 求めたスカラーパラメーターを表 3 にそれぞれ示す. 特異性指数 $\lambda_{m}$ には, $0<\lambda_{m}<1$ の範囲で值の小さいものから 順に $m=\mathrm{I}, \mathrm{II}, \mathrm{III}, \ldots$ と番号付けをし，スカラーパラメーター $C_{m}$ も特異性指数に対応するように $m=\mathrm{I}, \mathrm{II}, \mathrm{III}, \ldots$ と番 号付けを行っている. 特異性指数には, $-2<\lambda_{m}{ }^{*} \leq-1$ の範囲のものも示した. 表 2 に示すように $\lambda$ が固有值のとき,

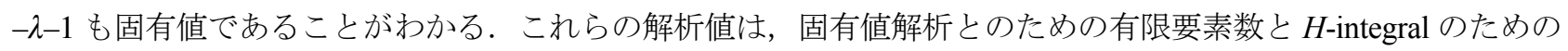
積分要素数が共に 2000 のものであり, 式 (8) では $\gamma=0.001$ としている. また, $H$-integral の積分半径は最小メッ シュサイズの 10 倍程度である $r=0.015 \mathrm{~mm}$ とした. 図 3 中の $\phi=\pi / 4, \theta=5 \pi / 12$ の位置での式(1)より求められる 漸近解と FEM の結果を図 4 に示寸. 図 4 より，特異点に非常に近いところでは FEM 結果が誤差を含むので一致 しなくなるということを除けば，漸近解と FEM がよく一致しており，精度よくスカラーパラメーターの計算を 行えていると考えられる. 
Koga, Taguchi, Koganemaru, Ikeda and Miyazaki, Transactions of the JSME (in Japanese), Vol.83, No.845 (2017)

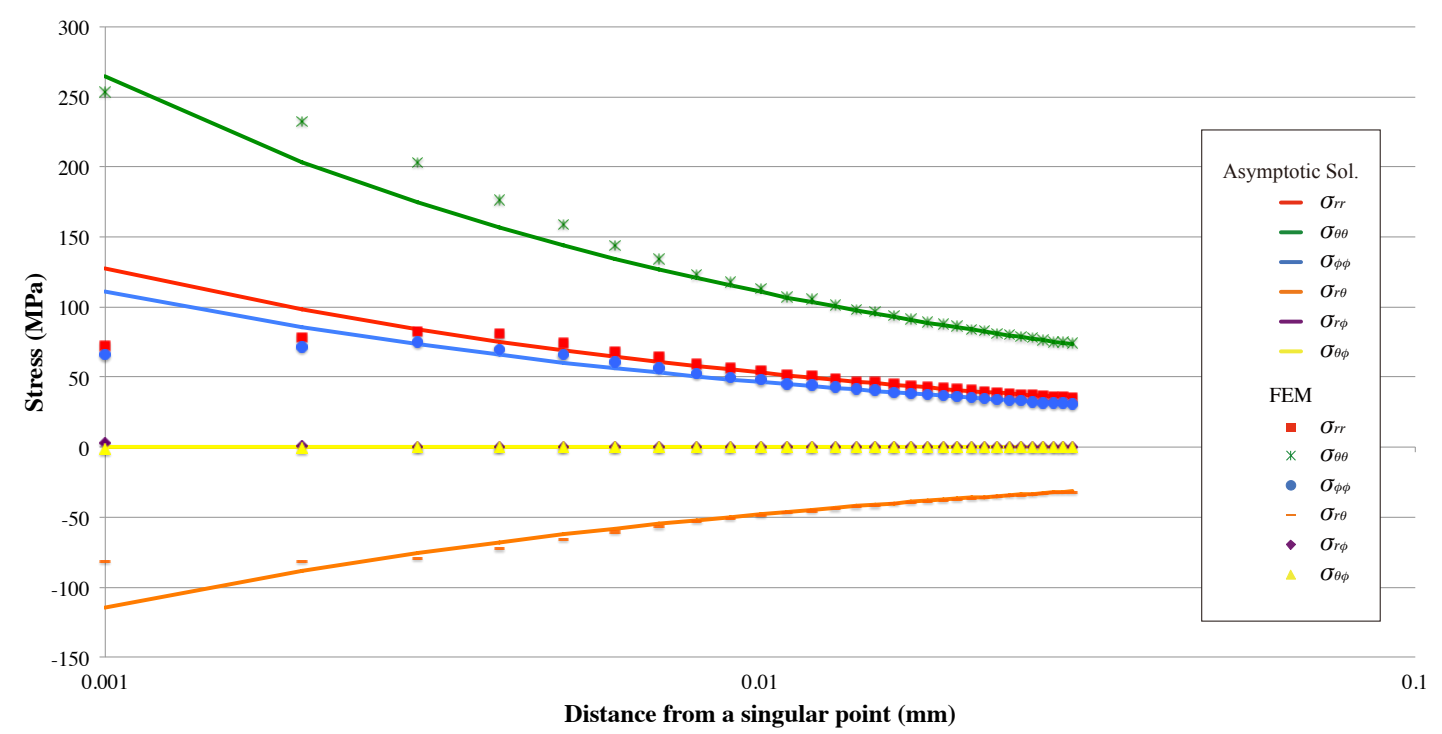

Fig. 4 Distributions of stresses at $\phi=\pi / 4, \theta=5 \pi / 12$ with the distance from a singular point (H-integral meshes $=2000$, Model I, Isotropic).

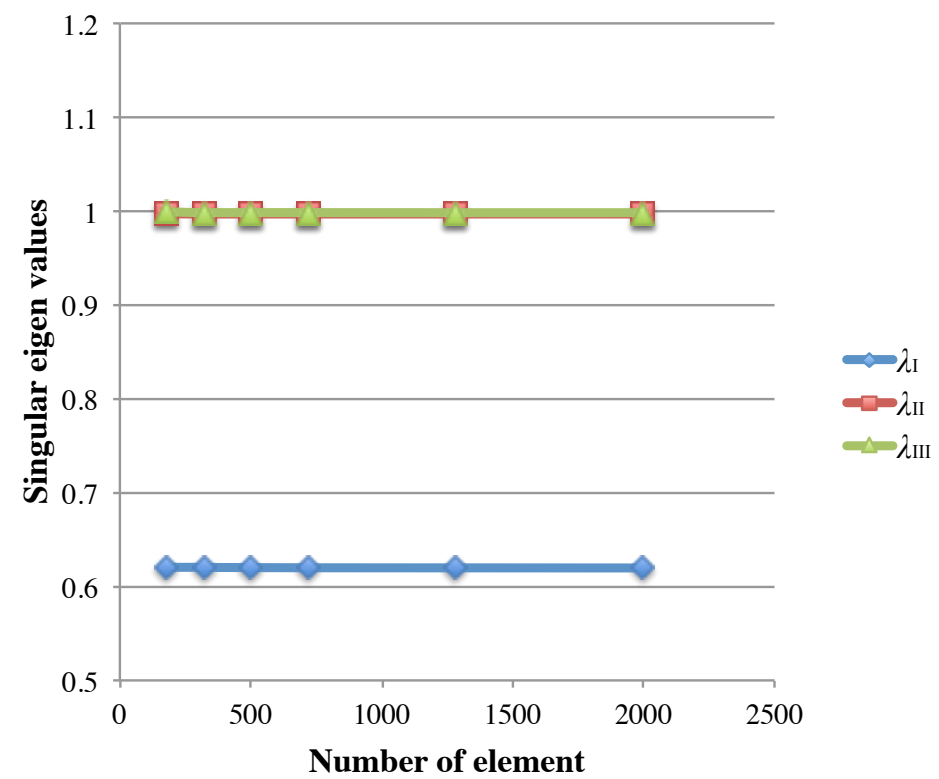

Fig. 5 Obtained singular eigenvalues with the number of FE elements in Fig. 1 (Model I, Isotropic).

また，式（15）の積分值を計算すると，表 4 に示すようにほぼ 0 とみなせる值であることがわかり，式(15)が 成立することを間接的に示している.

さらに, 固有値解析に用いた有限要素数と特異性固有值の関係を図 5 に, $H$-integral に用いた積分要素数とスカ ラーパラメーターとの関係を図 6 に示した。 これより, 固有值解析の有限要素数を増やしても, 得られた特異性 固有值やスカラーパラメーターの值が変化せず安定した計算が行えていることがわかる. また, 図 7 に $H$-integral の経路独立性を示した。これより，経路独立性も成り立っていることがわかる. 


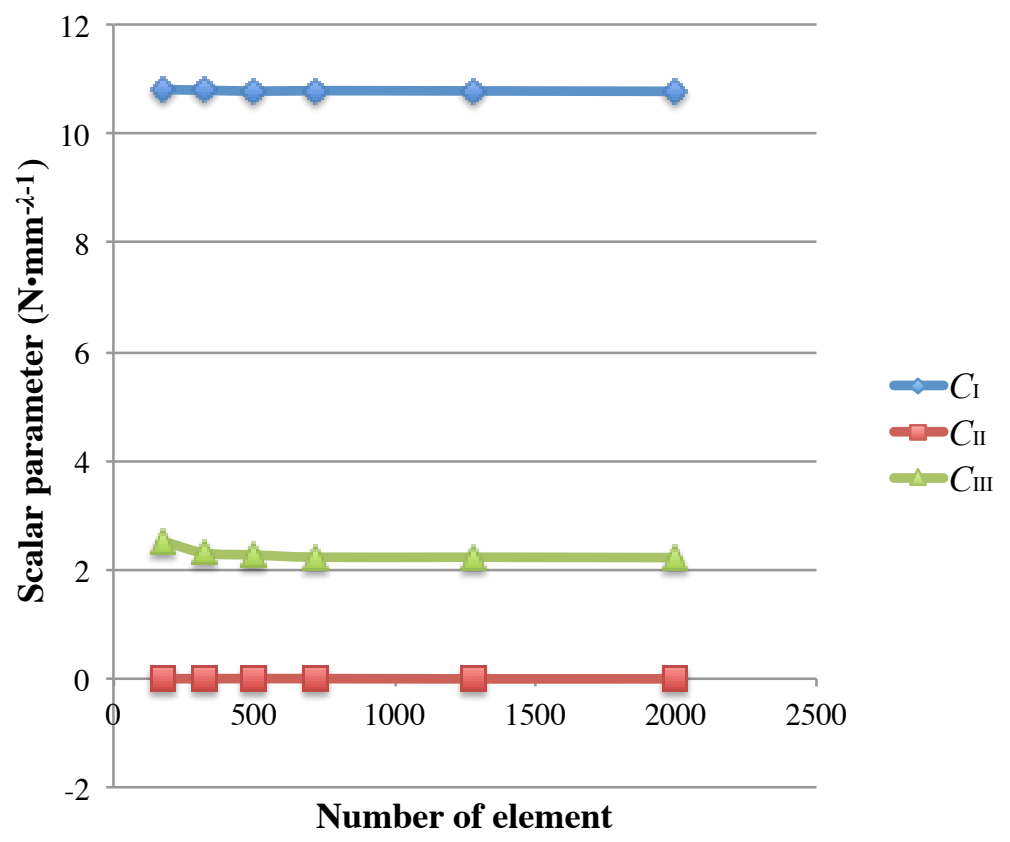

Fig. 6 Obtained scalar parameters with the number of $H$-integral meshes (Model I, Isotropic).

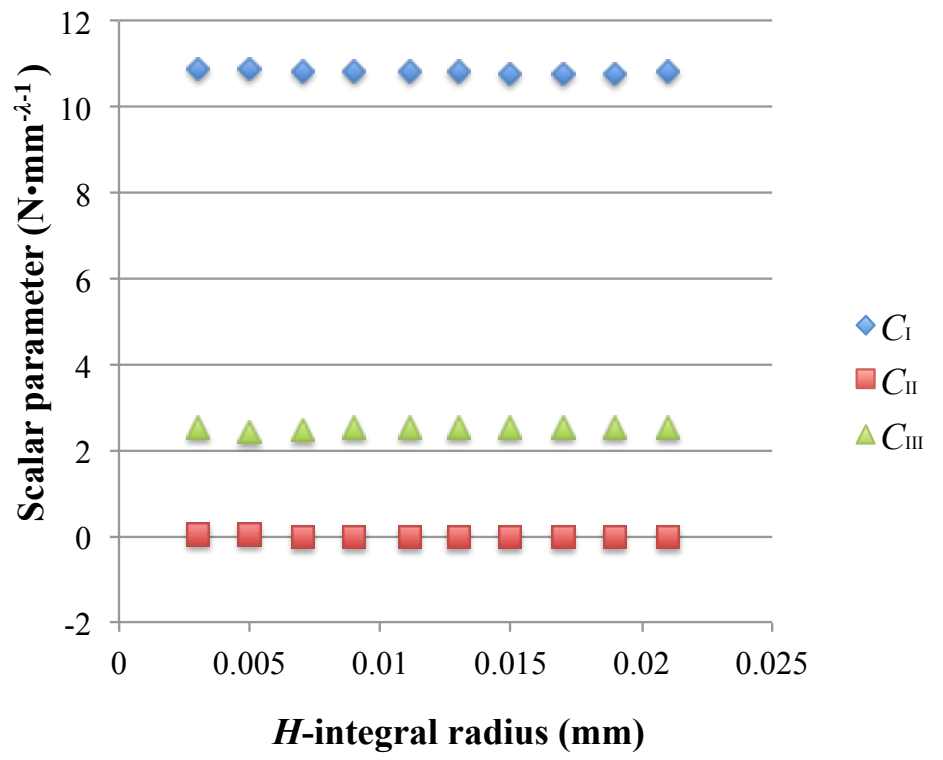

Fig. 7 Path independency of scalar parameters with the radius of $H$-integral (Model I, Isotropic, $H$-integral meshes=2000).

\section{$3 \cdot 1 \cdot 2$ 直交異方性材料と単斜晶材料の接合体の場合}

図 3 中の材料 1 として直交異方性材料, 材料 2 として単斜晶材料を仮定した。一様引張り $\sigma_{x x}^{0}=50.0 \mathrm{MPa}$ とし た. 用いた材料定数を表 5 に, 固有值分解の結果として求めた特異性指数を表 6 に, $H$-integral によって求めたス カラーパラメーターを表 7 にそれぞれ示す. 特異性指数 $\lambda_{m}$ には值の小さいものから順に $m=$ I, II, III, ...と番号付 けをし，スカラーパラメーター $C_{m}$ も特異性指数に対応するように $m=\mathrm{I}, \mathrm{II}, \mathrm{III}, \ldots$ と番号付けを行っている. これ らの解析值は, 固有值解析と $H$-integral のための有限要素数が 2000 のものであり, 式 (8) の $\gamma$ も $\gamma=0.001$ とした. また, $H$-integral の積分半径は最小メッシュサイズの 10 倍程度である $r=0.015 \mathrm{~mm}$ とした. ここでも, $\lambda_{m}$ が固有 值のときに, $-\lambda_{m}-1$ も固有值となっており, 表 8 に示した式(15)の值もほぼ 0 となっている. 図 3 中の $\phi=\pi / 4, \theta=$ 
$\pi / 4$ の位置での式(1)より求められる漸近解と FEM の結果を図 8 に示寸. 図 8 より, 特異点に非常に近いところ では FEM 結果が誤差を含むので一致しなくなるということを除けば，漸近解と FEM がよく一致しており，精度 よくスカラーパラメーターの計算を行えていると考えられる.

等方性材料の組み合わせの場合と同様に, 固有值解析と $H$-integral に用いた有限要素数と特異性固有值の関係 を図 9 に, スカラーパラメーターとの関係を図 10 に示した。 これより, 固有値解析の有限要素数を増やしても, 得られた特異性固有值やスカラーパラメーターの值が変化せず安定した計算が行えていることがわかる．また， 図 11 に有限要素数 2000 の場合の求めたスカラーパラメーターの経路独立性を示した. この場合も, $H$-integral の経路独立性はほぼ成立していることがわかる.

Table 5 Material properties of materials 1 and 2 in Fig. 3 (Model I, Anisotropic).

\begin{tabular}{ccc}
\hline & Material 1 (Aragonite: Orthotropic) & Material 2 (GSO: Monoclinic) \\
\hline$C_{11}(\mathrm{GPa})$ & 160 & 223 \\
\hline$C_{12}(\mathrm{GPa})$ & 36.6 & 108 \\
\hline$C_{13}(\mathrm{GPa})$ & 1.97 & 98.5 \\
\hline$C_{15}(\mathrm{GPa})$ & 0 & 8.4 \\
\hline$C_{22}(\mathrm{GPa})$ & 87 & 150 \\
\hline$C_{23}(\mathrm{GPa})$ & 15.9 & 102 \\
\hline$C_{25}(\mathrm{GPa})$ & 0 & 33.3 \\
\hline$C_{33}(\mathrm{GPa})$ & 85 & 251 \\
\hline$C_{35}(\mathrm{GPa})$ & 0 & -6 \\
\hline$C_{44}(\mathrm{GPa})$ & 41.3 & 78.8 \\
\hline$C_{46}(\mathrm{GPa})$ & 0 & 6.6 \\
\hline$C_{55}(\mathrm{GPa})$ & 25.6 & 68.8 \\
\hline$C_{66}(\mathrm{GPa})$ & 42.7 & 82.7 \\
\hline
\end{tabular}

Table 6 Obtained singular eigenvalues (FE Elements in Fig. 1=2000, Model I, Anisotropic).

\begin{tabular}{cccccccc}
\hline & $\lambda_{\text {III }}{ }^{*}$ & $\lambda_{\text {II }}{ }^{*}$ & $\lambda_{\mathrm{I}}{ }^{*}$ & & $\lambda_{\mathrm{I}}$ & $\lambda_{\text {II }}$ & $\lambda_{\text {III }}$ \\
\hline Eigenvalues & -1.9275 & -1.8385 & -1.4879 & -1.0000 & 0.4879 & 0.8385 & 0.9275 \\
\hline
\end{tabular}

Table 7 Obtained scalar parameters $(H$-integral meshes $=2000$, Model I, Anisotropic).

\begin{tabular}{cccc}
\hline$\left(\mathrm{N} \cdot \mathrm{mm}^{-1-\lambda}\right)$ & $C_{\mathrm{I}}$ & $C_{\mathrm{II}}$ & $C_{\text {III }}$ \\
\hline Scalar parameter & 0.0463 & -0.1024 & 0.5272 \\
\hline
\end{tabular}

Table $8 \quad$ Integrated values of Eq. (13) ( $H$-integral meshes $=2000$, Model I, Anisotropic).

\begin{tabular}{ccccccc}
\hline Elements & $l=\mathrm{I}, m=\mathrm{II}$ & $l=\mathrm{I}, m=\mathrm{III}$ & $l=\mathrm{II}, m=\mathrm{I}$ & $l=\mathrm{II}, m=\mathrm{III}$ & $l=\mathrm{III}, m=\mathrm{I}$ & $l=\mathrm{III}, m=\mathrm{II}$ \\
\hline 2000 & $6.551 \times 10^{-7}$ & $1.299 \times 10^{-7}$ & $3.344 \times 10^{-7}$ & $7.878 \times 10^{-7}$ & $7.664 \times 10^{-7}$ & $4.003 \times 10^{-7}$ \\
\hline
\end{tabular}




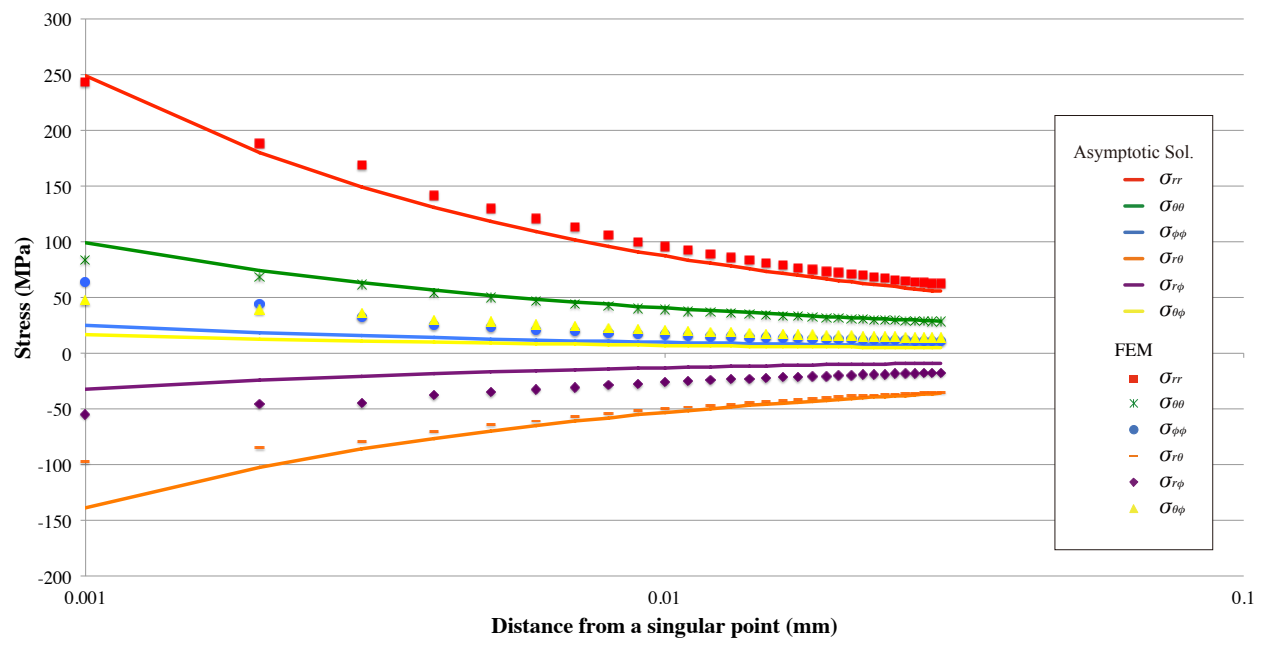

Fig. 8 Distributions of stresses at $\phi=\pi / 4, \theta=\pi / 4$ with the distance from a singular point $(H$-integral meshes $=2000$, Model I, Anisotropic $)$.

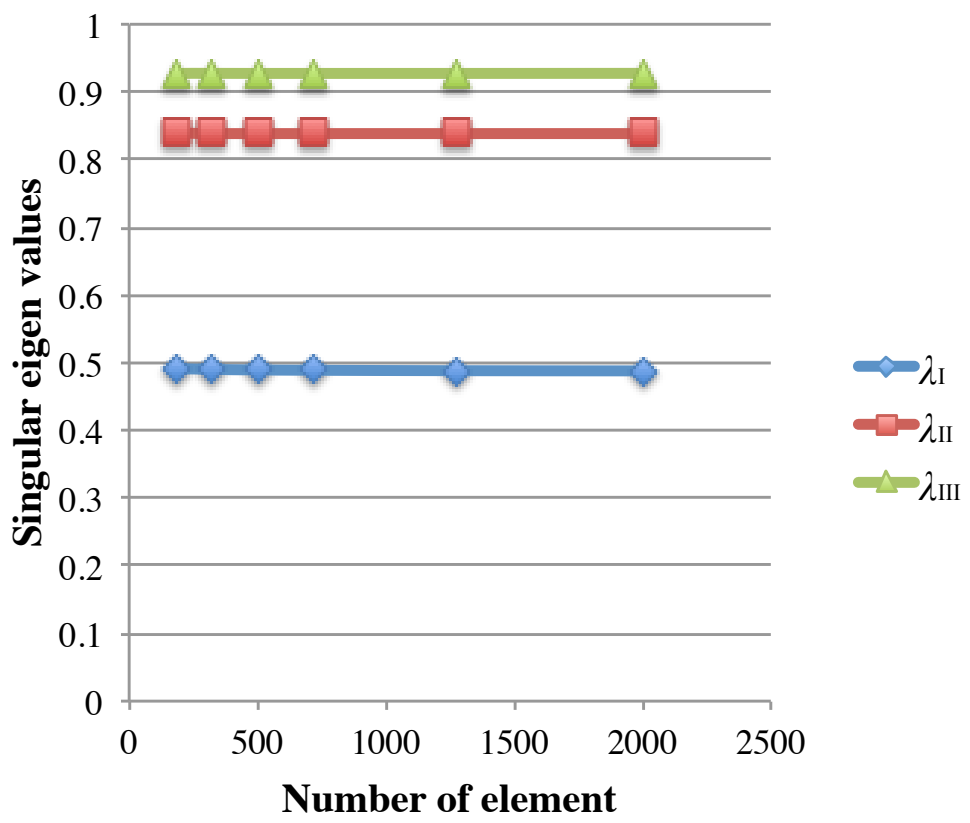

Fig. 9 Obtained singular eigenvalues with the number of FE elements in Fig. 1 (Model I, Anisotropic). 


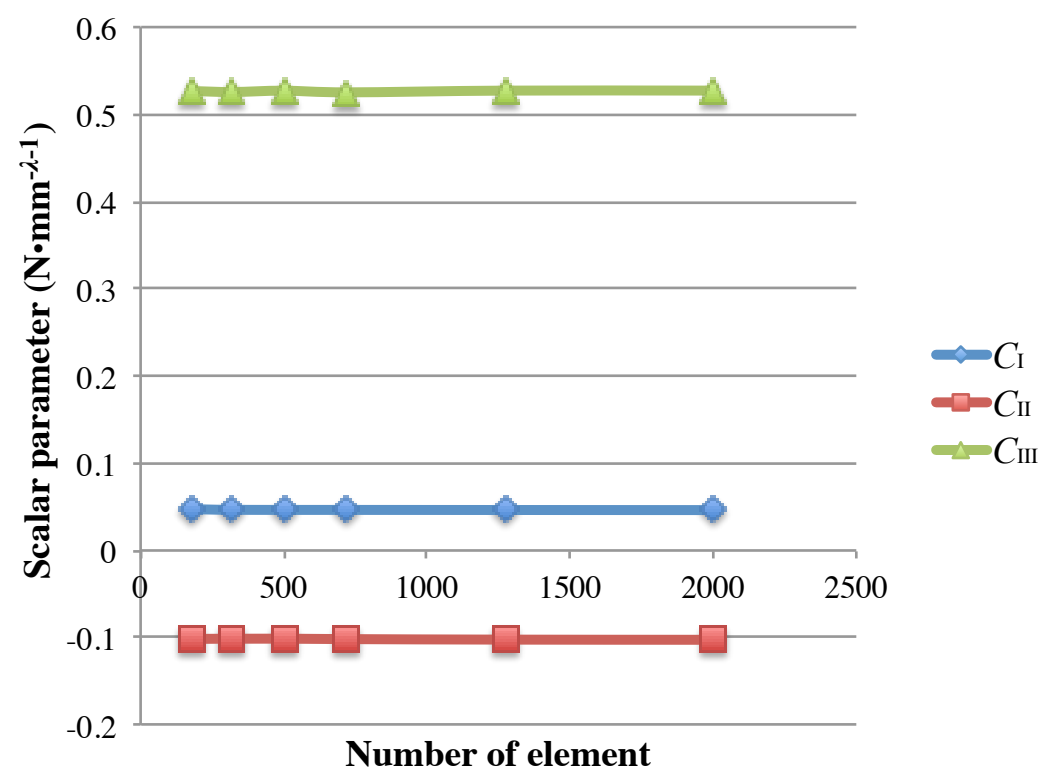

Fig. 10 Obtained scalar parameters, $C_{\mathrm{I}}, C_{\mathrm{I}}, C_{\mathrm{II}}$, with the number of $H$-integral meshes (Model I, Anisotropic).

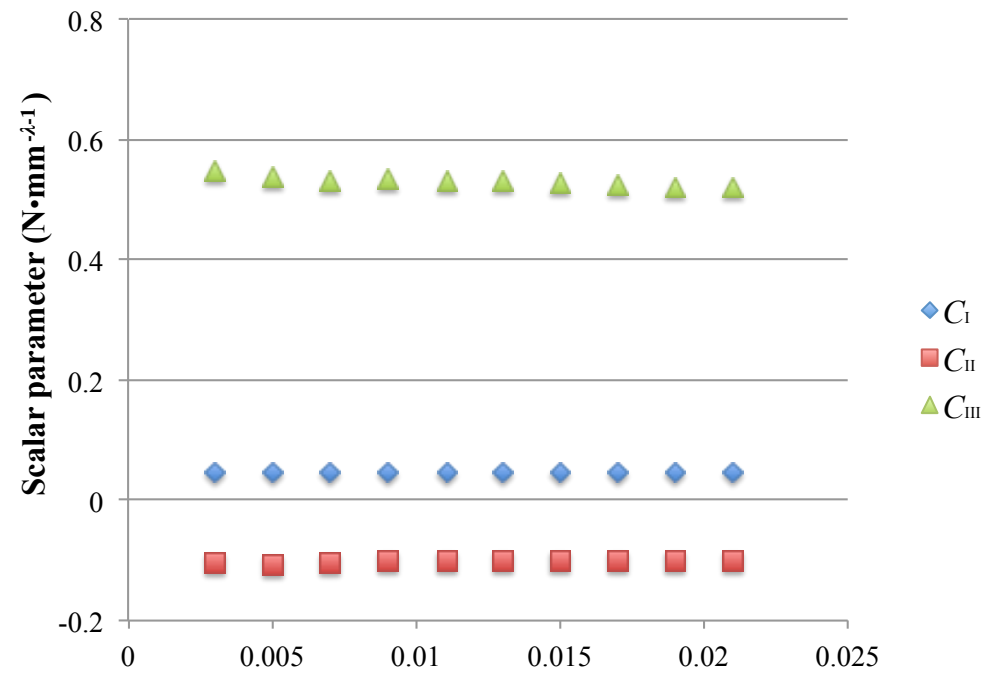

$H$-integral radius (mm)

Fig. 11 Path independency of scalar parameters, $C_{\mathrm{I}}, C_{\mathrm{II}}, C_{\mathrm{III}}$, with the radius of $H$-integral (Model I, Anisotropic, $H$-integral meshes=2000).

\section{$3 \cdot 2$ 異種材接合角部 II}

最後に解析モデルとして図 12 に示すような等方性材料の接合体に一様引張り $\sigma_{x x}^{0}=5.0 \mathrm{MPa}$ を加えた場合を解 析した. モデル形状は, $W=1.0 \mathrm{~mm}, L=1.0 \mathrm{~mm}$, 及び $t=1.0 \mathrm{~mm}$ とした. 用いた材料定数を表 9 に, 固有值分解 の結果として求めた特異性指数を表 10 に, $H$-integral によって求めたスカラーパラメーターを表 11 に示す. ここ では特異性指数が 1 つであることより, スカラーパラメーターも 1 つである. これらの解析值は, 固有值解析と $H$-integral のための有限要素数が 1800 のものであり, 式 (8) の $\gamma$ は $\gamma=0.001$ とした. また, $H$-integral の積分半径 
は最小メッシュサイズの 10 倍程度である $r=0.015 \mathrm{~mm}$ とした. 図 12 中の $\phi=\pi / 4, \theta=3 \pi / 4$ の位置での式(1)より 求められる漸近解と FEM の結果を図 13 に示す. 図 13 より, この場合も特異点に非常に近いところでは FEM 結 果が誤差を含むので一致しなくなるということを除けば，漸近解と FEM がよく一致しており，精度よくスカラ ーパラメーターの計算を行えていると考えられる.

この場合, 特異性固有值と対応したスカラーパラメーターが一対しか無いが, 固有值解析と $H$-integral に用い た有限要素数と特異性固有值の関係を図 14 に, スカラーパラメーターとの関係を図 15 に示した. ここでも, 固 有值解析の有限要素数を増やしても, 得られた特異性固有值やスカラーパラメーターの值が変化せず安定した計 算が行えていることがわかる. また, 図 16 に求めたスカラーパラメーターの経路独立性を示寸.この場合も, $H$-integral の経路独立性は良好であることがわかる.

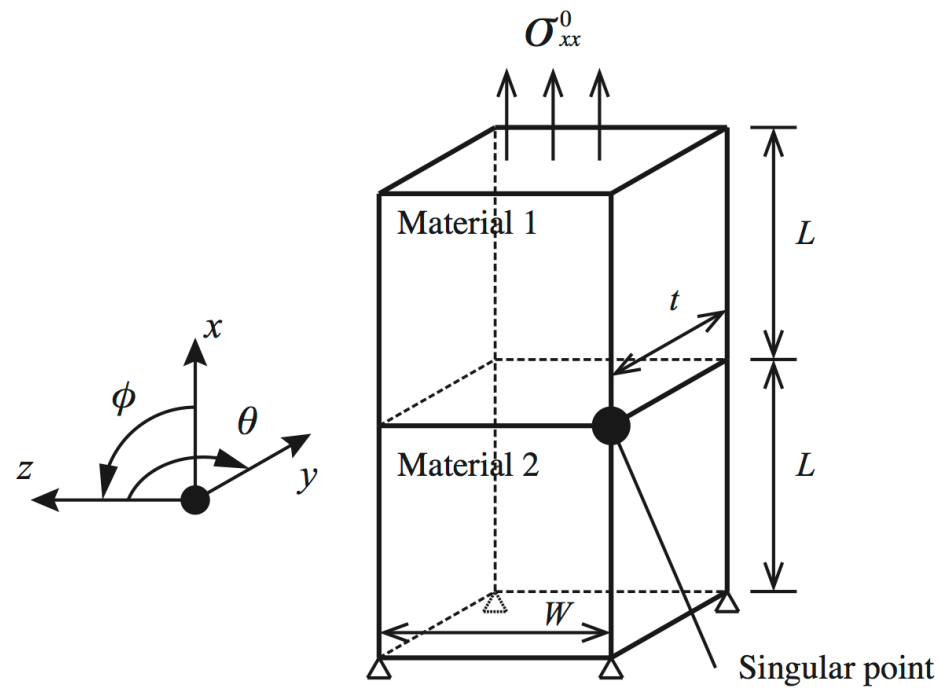

Fig. 12 Schematic of an analysis model (Model II).

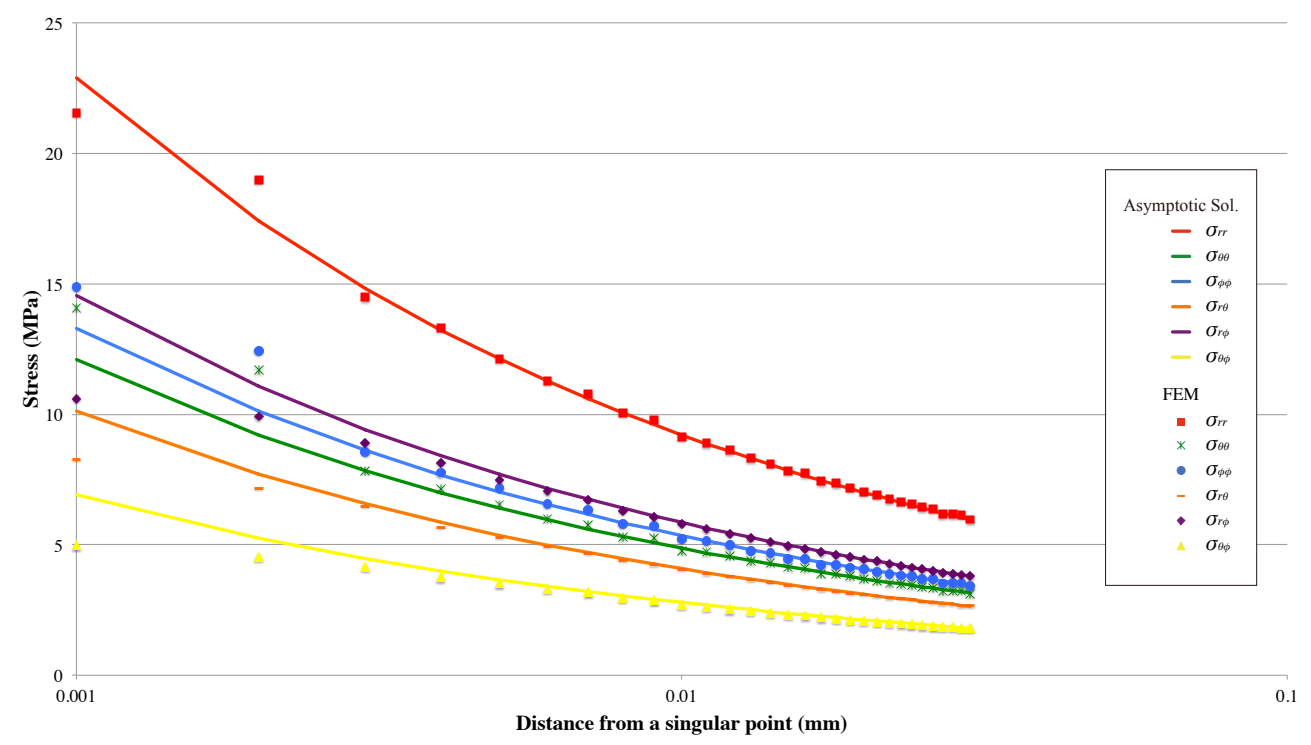

Fig. 13 Distributions of stresses at $\phi=\pi / 4, \theta=3 \pi / 4$ with the distance from a singular point (Model II, $H$-integral meshes $=1800$ ). 
Koga, Taguchi, Koganemaru, Ikeda and Miyazaki, Transactions of the JSME (in Japanese), Vol.83, No.845 (2017)

Table 9 Material properties of materials 1 and 2 in Fig. 12 (Model II).

\begin{tabular}{|c|c|c|c|}
\hline \multicolumn{2}{|c|}{ Material } & $1(\mathrm{Si})$ & 2 (Resin) \\
\hline Young's modulus & $E(\mathrm{GPa})$ & 166 & 2.74 \\
\hline Poisson's ratio & $v$ & 0.26 & 0.38 \\
\hline
\end{tabular}

Table 10 Obtained eigenvalues (Model II, Fe elements in Fig. $1=1800$ ).

\begin{tabular}{cccc}
\hline & $\lambda_{\mathrm{I}}{ }^{*}$ & $\lambda_{\mathrm{I}}$ & \\
\hline Eignenvalues & -1.6046 & -1.0000 & 0.6046 \\
\hline
\end{tabular}

Table 11 Obtained scalar parameter (Model II, $H$-integral meshes $=1800)$.

\begin{tabular}{cc}
\hline$\left(\mathrm{N} \cdot \mathrm{mm}^{-1-\lambda}\right)$ & $C_{\mathrm{I}}$ \\
\hline Scalar parameter & -0.4457 \\
\hline
\end{tabular}

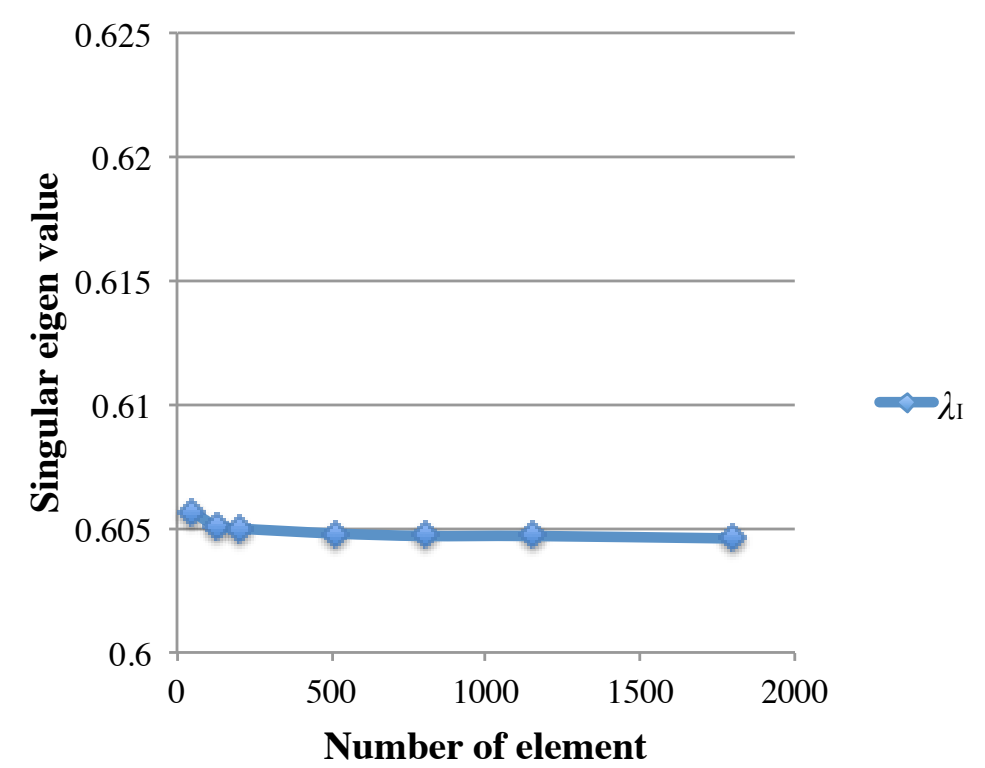

Fig. 14 Obtained singular eigenvalues with the number of FE elements in Fig. 1 (Model II). 


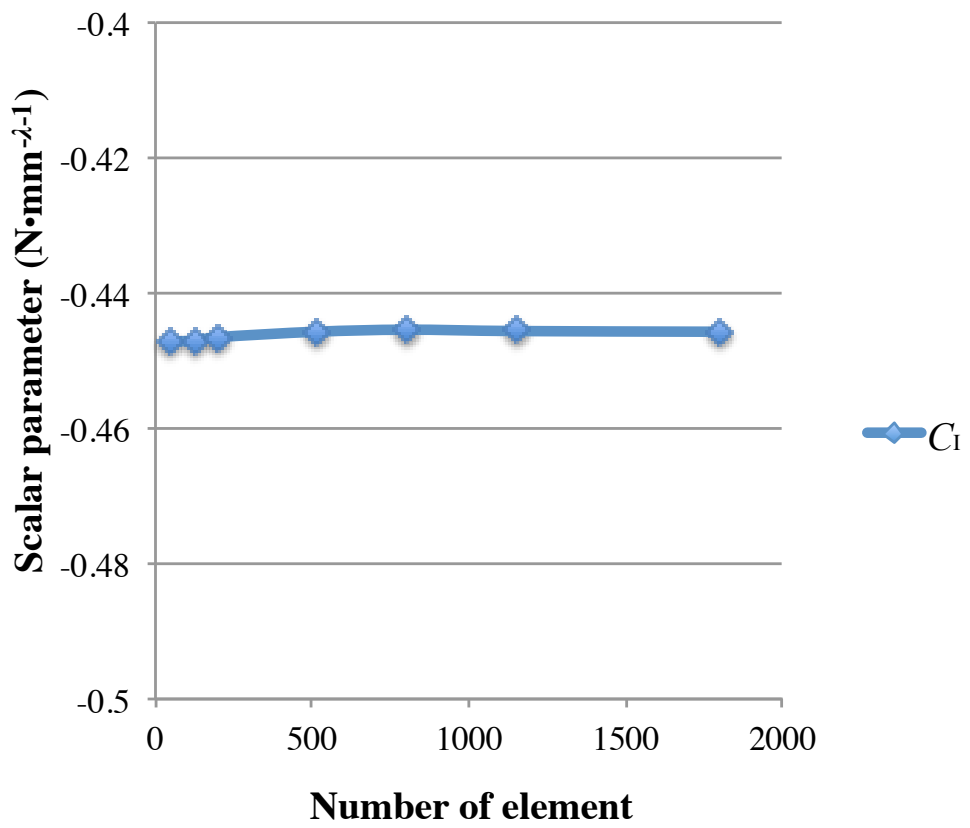

Fig. 15 Obtained scalar parameter with the number of $H$-integral meshes (Model II).

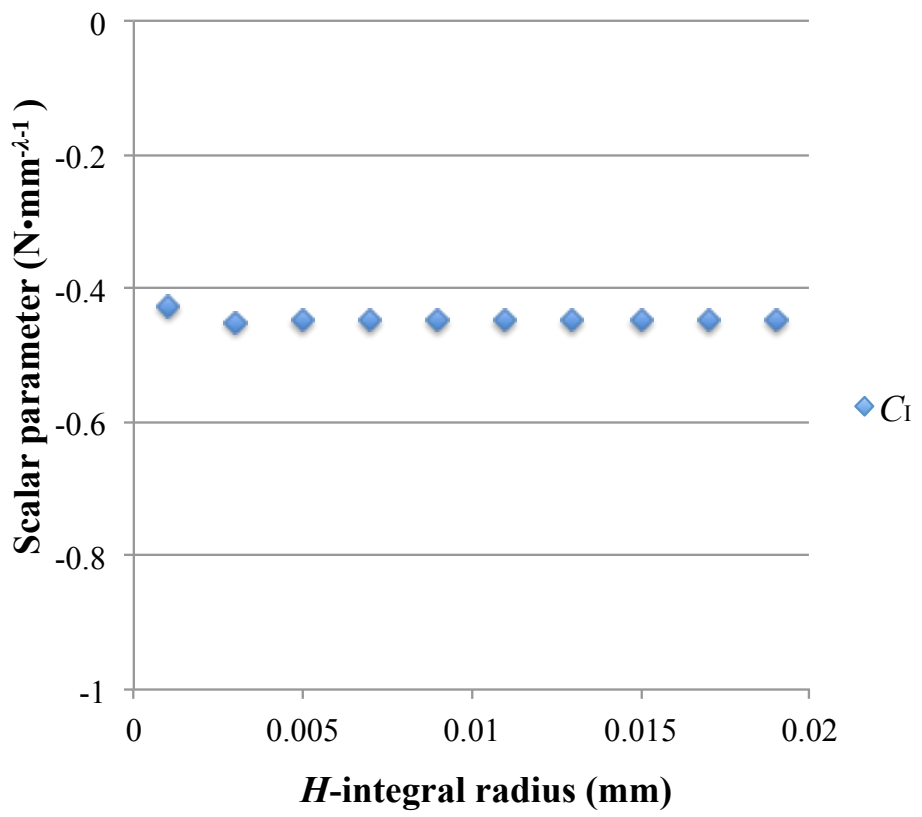

Fig. 16 Path independency of a scalar parameter with the radius of $H$-integral (Model II, $H$-integral meshes=1800).

\section{4. 結 言}

本研究では Pageau らによる有限要素解析の手法を用いることで異種材接合角部の三次元角部での特異性指数 の解析を行った.さらにWilliams の固有值展開法と Pageau らによる有限要素解析の手法を組み合わせて $H$-integral を行い，スカラーパラメーターの計算を行った．この際に $0<\lambda<1$ の範囲にある応力が特異性を示す固有值に対 して， $-\lambda-1$ を補助解に用いることで， $H$-integral により有効にスカラーパラメーターを求めることができた. こ の方法は，基本的に(Luangarpa and Koguchi, 2014) の手法と同様であるが，この論文ではスカラーパラメーターが 単一実数の場合しか求められなかったものを, 本研究では複数のスカラーパラメーターを同時に $H$-integral で計 算する手法に拡張し，その有効性を半解析的に証明した. 
また，これまで計算により得られたスカラーパラメーターは固有值解析の有限要素数を増やすことで変化して いたが，式（8）で固有ベクトルを一意的に定義することで，一定值に収束する安定したスカラーパラメーターの 計算を行えることを示した。 このことで，スカラーパラメーターを破壊力学パラメーターに結びつける基礎が確 立した. さらに求めたスカラーパラメーターより得られる漸近解を角部近傍を十分に細かく要素分割した有限要 素法より求めた応力場と比較すると, 有限要素法の精度が低下寸ると考えられる三次元角部のごく近傍を除いて, 両者は良く一致しており，求めたスカラーパラメーターの精度の良さを間接的に示している. このように三次元 角部周りの複雑な応力場を数個のスカラーパラメーターで記述できるようになったことにより, 三次元角部から の破壊を定量的に評価するための基礎的な手法が確立できたと考えられる.

\section{文献}

Banks-Sills, L. and Ishbir, C., A conservative integral for bimaterials notches subjected to thermal stresses, International Journal for Numerical Methods in Engineering, Vol.60 (2004), pp.1075-1102.

Carpenter, W.C., Calculation of fracture mechanics parameters for a general corner, International Journal of Fracture, Vol. 24 (1984), pp. 45-58.

Hwu, C. and Kuo, T. L., A unified definition for stress intensity factors of interface corners and cracks, International Journal of Solids and Structures, Vol.44 (2007), pp.6340-6359.

Hwu, C., Omiya, M. and Kishimoto, K., A key matrix $\hat{\mathrm{N}}$ for the stress singularity of the anisotropic elastic composite wedges, Japan Society of Mechanical Engineers International Journal Series A, Vol.46 (2003), pp.40-50.

池田徹, 田口陽介, 宮崎則幸, $H$-integral による三次元異方性異種接合角部のスカラーパラメーターの解析, M\&M 材料力学カンファレンス講演論文集 (2013), OS0101.

Koguchi, H. and Muramoto, T., The order of stress singularity near the vertex in three-dimensional joints, International Journal of Solids and Structures, Vol. 37, No. 35 (2000), pp. 4737-4762.

Labossiere, P. E. W. and Dunn, M. L., Stress interface corners in anisotropic bimaterials, Engineering Fracture Mechanics, Vol.62 (1999), pp.555-575.

Luangarpa, C. and Koguchi, H., Analysis of a three-dimensional dissimilar material joint with one real singularity using a conservative integral, International Journal of Solids and Structures, Vol. 51, No. 15-16 (2014), pp. 2908-2919.

Munz, D., Fett, T. and Yang, Y. Y., The regular stress term in bonded dissimilar materials after a change in temperature, Engineering Fracture Mechanics, Vol.44 (1993), pp.185-194.

Nomura, Y., Ikeda, T. and Miyazaki, N., Stress intensity factor analysis of a three-dimensional interfacial corner between anisotropic bimaterials under thermal stress, International Journal of Solids and Structures, Vol. 47 (2010), pp. 1775-1784.

Nomura, Y., Ikeda, T. and Miyazaki, N., Stress intensity factor analysis at an interfacial corner between anisotropic bimaterials under thermal stress, Engineering Fracture Mechanics, Vol.76 (2009), pp221-235.

Pageau, S. S. and Biggers, S. B., Finite element evaluation of free-edge singular stress fields in anisotropic materials, International Journal for Numerical Methods in Engineering, Vol.38 (1995), pp.2225-2239.

Sinclair, G.B., Okajima, M. and Griffin, J.H., Path independent integrals for computing stress intensity factors at sharp notches in elastic plates, International Journal for Numerical Methods in Engineering, Vol. 20 (1984), pp. 999-1008.

Stern, M., Becker, E.B. and Dunham, R.S., A contour integral computation of mixed-mode stress intensity factors, International Journal of Fracture, Vol. 12 (1976), pp. 359-368.

Williams, M.L., Stress singularities resulting from various boundary conditions in angular corners of plates in extension, Journal of Applied Mechanics, Transactions ASME, Vol. 19 (1952), pp. 526-528.

Williams, M.L., On the stress distribution at the base of a stationary crack, Journal of Applied Mechanics, Transactions ASME, Vol. 24 (1957), pp. 109-114.

Wu, K.C. and Chang, F.T., Near-tip fields in a notched body with dislocations and body forces, Journal of Applied Mechanics, Transactions ASME, Vol. 60 (1993), pp. 936-941.

\section{References}

Banks-Sills, L. and Ishbir, C., A conservative integral for bimaterials notches subjected to thermal stresses, International Journal for Numerical Methods in Engineering, Vol.60 (2004), pp.1075-1102. 
Carpenter, W.C., Calculation of fracture mechanics parameters for a general corner, International Journal of Fracture, Vol. 24 (1984), pp. 45-58.

Hwu, C. and Kuo, T. L., A unified definition for stress intensity factors of interface corners and cracks, International Journal of Solids and Structures, Vol.44 (2007), pp.6340-6359.

Hwu, C., Omiya, M. and Kishimoto, K., A key matrix $\hat{N}$ for the stress singularity of the anisotropic elastic composite wedges, Japan Society of Mechanical Engineers International Journal Series A, Vol.46 (2003), pp.40-50.

Ikeda, T., Taguchi, Y. and Miyazaki, N., Analysis of scholar parameters at three dimensional jointed corners among anisotropic dissimilar materials using the H-integral, Proceedings of JSME M\&M conference 2013 (2013), OS0101, (in Japanese).

Koguchi, H. and Muramoto, T., The order of stress singularity near the vertex in three-dimensional joints, International Journal of Solids and Structures, Vol. 37, No. 35 (2000), pp. 4737-4762.

Labossiere, P. E. W. and Dunn, M. L., Stress interface corners in anisotropic bimaterials, Engineering Fracture Mechanics, Vol.62 (1999), pp.555-575.

Luangarpa, C. and Koguchi, H., Analysis of a three-dimensional dissimilar material joint with one real singularity using a conservative integral, International Journal of Solids and Structures, Vol. 51, No. 15-16 (2014), pp. 2908-2919.

Munz, D., Fett, T. and Yang, Y. Y., The regular stress term in bonded dissimilar materials after a change in temperature, Engineering Fracture Mechanics, Vol.44 (1993), pp.185-194.

Nomura, Y., Ikeda, T. and Miyazaki, N., Stress intensity factor analysis of a three-dimensional interfacial corner between anisotropic bimaterials under thermal stress, International Journal of Solids and Structures, Vol. 47 (2010), pp. 1775-1784.

Nomura, Y., Ikeda, T. and Miyazaki, N., Stress intensity factor analysis at an interfacial corner between anisotropic bimaterials under thermal stress, Engineering Fracture Mechanics, Vol.76 (2009), pp221-235.

Pageau, S. S. and Biggers, S. B., Finite element evaluation of free-edge singular stress fields in anisotropic materials, International Journal for Numerical Methods in Engineering, Vol.38 (1995), pp.2225-2239.

Sinclair, G.B., Okajima, M. and Griffin, J.H., Path independent integrals for computing stress intensity factors at sharp notches in elastic plates, International Journal for Numerical Methods in Engineering, Vol. 20 (1984), pp. 999-1008.

Stern, M., Becker, E.B. and Dunham, R.S., A contour integral computation of mixed-mode stress intensity factors, International Journal of Fracture, Vol. 12 (1976), pp. 359-368.

Williams, M.L., Stress singularities resulting from various boundary conditions in angular corners of plates in extension, Journal of Applied Mechanics, Transactions ASME, Vol. 19 (1952), pp. 526-528.

Williams, M.L., On the stress distribution at the base of a stationary crack, Journal of Applied Mechanics, Transactions ASME, Vol. 24 (1957), pp. 109-114.

Wu, K.C. and Chang, F.T., Near-tip fields in a notched body with dislocations and body forces, Journal of Applied Mechanics, Transactions ASME, Vol. 60 (1993), pp. 936-941. 